\title{
TÜRKİYE'DEKİ DİŞ HEKİMLERİNİN KONJENİTAL DAİMİ DİŞ EKSİKLİĞİNDE TEDAVİ YAKLAŞIMI ve TUTUMU
}

\author{
APPROACHES AND ATTITUDES OF TURKISH DENTISTS IN CASES OF \\ CONGENITAL PERMANENT TOOTH AGENESIS
}

\author{
Dr.Öğr.Üyesi Aslı SOĞUKPINAR* \\ Dr.Öğr.Üyesi Katibe Tuğçe TEMUR ${ }^{* *}$ \\ Dr. Öğr. Üyesi Ömer HATİPoĞLU**
}

Makale Kodu/Article code: 4326

Makale Gönderilme tarihi: 25.02.2020

Kabul Tarihi: 13.08 .2020

DOI : $10.17567 /$ ataunidfd. 780163
Aslı Soğukpınar : ORCID ID: 0000-0002-1934-9945

Katibe Tuğçe Temur: ORCID ID: 0000-0001-9947-5679

Ömer Hatipoğlu: ORCID ID: 0000-0002-4628-8551

\section{öz}

Amaç: Konjenital daimi diş eksikliğinin etiyolojisi tam olarak bilinmemekle birlikte genetik ve çevresel faktörlerden kaynaklandığı düşünülmektedir. Diş eksikliğinin çiğneme, konuşma, beslenme, estetik ve psikolojik sorunlara yol açtığı bilinmektedir. Bu çalışmanın amacı Türkiye'de çalışan diş hekimlerinin konjenital daimi diş eksikliği konusunda bilgi ve tutumlarının değerlendirilmesi ve tedavi farkındalı̆ının artırılmasıdır.

Materyal ve Metot: Çalışmamıza sosyal medya üzerinden (facebook, instagram, e-mail) ulaşılan Türkiye'de çalışan 244 diş hekimi dahil edildi. 13 soruyu içeren anket formu diş hekimlerine gönderildi. Birinci bölümde demografik veriler soruldu. İkinci bölümde ise diş hekimlerine konjenital daimi diş eksikliği konusunda genel yaklaşımları hakkında sorular soruldu. Veriler tanımlayıcı istatistikler ve Ki-kare testi ile analiz edildi.

Bulgular: Bu kesitsel çalışmaya katılan diş hekimlerinin \%52,5'i konjenital daimi diş eksikliği konusunda yeterli bilgiye sahip olduklarını belirtmişken, $\% 47,5^{\prime} i$ yeterli bilgiye sahip olmadıklarını düşünmüştür. Çalışmaya katılanların konjenital daimi diş eksikliğinde tedavi planlamasını yaparken sırasıyla \%78,1'i dişin fonksiyon görmesine ve \%0,6'sı işlemin kısa sürmesine göre karar vermiştir.

Sonuç: Türkiye'de diş hekimlerinin konjenital daimi diş eksikliğine ilişkin eğitimi yeterli olmayıp, diş hekimlerinin bu konuda daha fazla pratik ve teorik eğitime intiyacı vardır.

Anahtar Kelimeler: Konjenital, Bilgi, Çocuk, Diş eksikliği

\section{ABSTRACT}

Aim: Although the etiology of congenital permanent tooth agenesis is not known entirely, it is thought that it is due to genetic and environmental factors. It is known that tooth aganesis causes chewing, speech, nutrition, aesthetic and psychological problems. The purpose of this study was to assess the knowledge and behaviour of the dental practitioners working in Turkey about congenital permanent tooth agenesis; and to improve cognizance for the treatment.

Materials and Methods: 244 dentists who were reached via social media (facebook, instagram, e-mail) were included in our study. The questionnaire which include 13 questions was sent to dental practitioners. In the first part, the demographical data were asked. In the second part, general approaches of dental practitioners about congenital permanent tooth agenesis were asked, too. Data were analyzed using descriptive statistics and Chi-square test.

Results: While $52.5 \%$ of the dental practitioners who participated in this cross-sectional study stated that they had sufficient information about congenital tooth deficiency, $47.5 \%$ thought that they did not have enough information. As the participants are deciding to treatment planning about congenital permanent tooth agenesis, they took into account the factors of function of the tooth $(78.1 \%)$ and short period of time $(0.6 \%)$ much more and less, respectively.

Conclusion: Education in Turkey related to congenital permanent tooth agenesis is not enough and the dental practitioners need more practical and theoretical training on this subject.

Keywords: Congenital, Knowledge, Paediatric, Tooth agenesis

${ }^{*}$ Kahramanmaraş Sütçü Imam Üniversitesi, Diş Hekimliği Fakültesi, Pedodonti AD, Kahramanmaraş

${ }^{* *}$ Kahramanmaraş Sütçü Imam Üniversitesi, Diş Hekimliği Fakültesi, Ağız Diş ve Çene Radyoloji AD, Kahramanmaraş

*** Ömer Halis Demir Üniversitesi, Restoratif Diş Tedavisi AD, Niğde

Kaynakça Bilgisi: Soğukpınar A, Temur KT, Hatipoğlu Ö. Türkiye'deki diş hekimlerinin konjenital daimi diş eksikliğinde tedavi yaklaşımı ve tutumu. Atatürk Üniv Diş Hek Fak Derg 2020; 30: 579-85.

Citation Information: Sogukpinar $A$, Temur KT, Hatipoglu $O$. Investigation approaches and attitudes of Turkish dentists in cases of congenital permanent tooth agenesis. J Dent Fac Atatürk Uni 2020; 30: 579-85 


\section{GİRİş}

Konjenital ikinci premolar eksikliği, üçüncü molarlar dışında en fazla rastlanılan dişsel anomalidir. ${ }^{1}$ Hipodonti; altıdan daha az sayıda dişin (üçüncü molarlar hariç) gelişimsel yokluğudur. Oligodonti; altı veya daha fazla dişin (üçüncü molarlar hariç) yokluğunu, anadonti ise tüm dişlerin eksik olmasını ifade etmektedir. ${ }^{2}$ Konjenital diş eksikliğinin etiyolojisinde etkili faktörler araştırmacılar tarafından tam olarak tanımlanamasa da, bu durumun, genetik ve çevresel etkenlerden kaynaklandığı düşünülmektedir. ${ }^{3,4}$

Konjenital daimi diş eksikliğinin değerlendirilmesinde öncelikle aileden detaylı bir anamnez alınmalı, multidisipliner (çocuk diş hekimi, ortodontist, ağız diş ve çene cerrahi uzmanı ve protez uzmanı) bir yaklaşım göz önünde tutulmalıdır. ${ }^{5-7}$ Konjenital daimi diş eksikliğine ek olarak süt molar diş kaybı çocukta çiğneme, konuşma, beslenme, estetik ve psikolojik sorunlara yol açması nedeniyle klinisyenler süt molar dişlerin tedavisine yönelmektedir. ${ }^{8}$ Diğer taraftan söz konusu anomali sonucunda infraokluze kalan süt molar dişlerin zamanla alveolar kemik yüksekliğinde azalması, karşıt arktaki dişlerde supraerüpsiyon, komşu dişlerin arktaki boşluğa doğru tipping hareketi, gelişimin etkilendiği tarafa doğru orta hattın kayması, daimi dişlerde sürme bozuklukları ve gelişim bozukluğu, süt molar dişlerin eksfoliasyonunda gecikme, komşu dişlerde çürüğe yatkınlık gibi sorunlar görülmektedir. ${ }^{9}$

Bu amaçla tedavi planlamasına karar verirken; arkta yer varlığı ya da yokluğu, hastanın yüz profili ve malokluzyon varlı̆ı değerlendirilmelidir. ${ }^{10}$

Literatürde hekimler tarafından yapılan klinik ve radyografik araştırmalar konjenital daimi diş eksikliğinde süt dişlerinin tedavisinde fikir birliği sağlanamadığı yönündedir.

Türkiye'deki çocuk diş hekiminin yeterli sayıda olmaması diş hekimlerinin de çocuk hastayı tedavi etmesini gerektirmektedir. Bildiğimiz kadarıyla diş hekimlerinin konjenital daimi diş eksikliği hakkında bilgi ve tutumlarını değerlendiren literatürde bir çalışma bulunmamaktadır.

Bu çalışmada Türkiye'de çalışan diş hekimlerinin konjenital daimi diş eksikliği konusunda bilgi ve tutumlarının değerlendirilmesi ve tedavi farkındalığının arttırılması amaçlandı.

\section{MATERYAL VE METOD}

Etik kurul onayı ve gerekli resmi izinler: Çalışmanın etik kurul onayı Kahramanmaraş Sütçü
İmam Üniversitesi, Tıp Fakültesi, Klinik Bilimler Etik Kurulundan alınmıştır (19.06.2019 tarih ve 2019/191 nolu).

Araştırmanın tipi: Araştırma kesitsel bir anket çalışmasıdır.

Örneklem büyüklüğü: Örneklem büyüklüğü Raosoft web anket yazılımı (http://www.raosoft.com/ samplesize.html) kullanılarak hesaplanmışıı. \% 85 güven aralığı, \% 5 alfa hatası, 26674 diş hekimi sayısına göre (Türkiye'deki TÜIK istatistik verileri) 206 katılımcıya gereksinim olduğu hesaplanmıştır.

Çalışma dizaynı: Google formları kullanılarak oluşturulan anket, sosyal medya (facebook, instagram, e-mail) üzerinden yaklaşık 2000 diş hekimine gönderilmiştir. Katılımcılara bilgilendirilmiş gönüllü olur formunu imzalandıktan sonra anketteki sorular yöneltilmiştir. Çalışmaya toplam 244 diş hekimi katılmışır. Çalışma 13 sorudan oluşup, 2 bölüm halinde hazırlanmıştır. Anketin ilk kısmında diş hekimlerinin cinsiyet, mesleki deneyimleri, çalışıı̆ı kurum gibi demografik özellikler yer almaktadır (Soru 1-3). İkinci kısımda ise konjenital daimi diş eksikliği konusunda diş hekimlerinin bilgi ve tedavi yaklaşımı hakkında sorular bulunmaktadır (Soru 4-13). Çalışmada sorulan anket soruları Tablo 1'de yer almaktadır.

\section{İstatistiksel Analiz}

Veri analizi Sosyal Bilimler 23.0 sürümü (SPSS Inc., Chicago, IL., USA) İstatistik Paketi kullanılarak yapılmışır. Tanımlayıcı istatikler ve ki-kare testi kullanılmıştır. İstatistiksel anlamlıık için olasılık düzeyi $p=0,05$ olarak belirlenmiştir.

\section{BULGULAR}

Çalışmaya katılan 244 diş hekiminin 166'sı kadın (\%68), 78'i erkektir (\%32). 10 yıldan az mesleki deneyimi olan diş hekimi sayısı 224 (\%91,8), 10 yıldan fazla mesleki deneyimi bulunan kişi sayısı ise 20 $(\% 8,2)$ 'dir. Çalışmada yer alan 127 kişi (\%52) özel klinikte, 117 kişi (\%48) ise devlet kurumunda çalışmaktadır (Tablo 2).

Çalışmaya katılanların \%52,5'i konjenital daimi diş eksikliği konusunda yeterli bilgiye sahipken, $\% 47,5^{\prime} i$ yeterli bilgiye sahip olmadığını düşünmektedir. Kadınlar erkeklere göre konjenital daimi diş eksikliği konusunda anlamlı olarak daha fazla yeterli bilgiye sahip olduğunu belirtirken $(p=0,013)$, çalışma yeri ve tecrübe açııından anlamlı bir fark bulunmadı $(p>0,05)$ (Tablo 3). Çalışmada yer alan diş hekimlerinin konjenital daimi diş eksikliğine yeterli bilgiye sahip olmadığını düşünenlerin; \%64,5'i pratik bilgiye sahip olmadığını, \%22,3'ü teorik bilgiye sahip olmadığını, \%10,7'si 
çocuk hastayı tedavi etmenin zorluğunu, \%19'u çocuk hastaya yaklaşım konusunda yeterli olmadığını, $\% 21,5^{\prime} i$ hatalı işlem yapabileceğini bildirmiştir (Resim $1)$.

Tablo 1. Anket formu

\section{Cinsiyetiniz}

a)Kadın

b)Erkek

2.Meslekteki kaçıncı yılınız

a) 10 yıldan az

b) 10 yildan fazla

3)Çalıştığınız kurum

a)Devlet

b)Özel

4.Konjenital daimi diş eksikliğine sahip çocuk hastada tedavi yaklaşımı

konusunda yeterli bilgiye sahip olduğunuzu düşünüyor musunuz?

a)Evet

b)Hayır

5.Cevabınız hayırsa hastayı tedavi etmeme nedeniniz nelerdir? (S1)

a)Teorik bilgi konusunda yeterli olmadığımı düşünüyorum

b)Yeterli Pratik tecrübeye sahip değilim

c) Cocuk hastayı tedavi etmenin zorluğu

d)Çocuk hastaya yaklaşım konusunda yeterli olmadığımı düşünüyorum

e)Hatalı işlem yapabileceğimi düşünmem

6.Yukarıdaki soruya cevabınız evetse konjenital daimi diş eksikliğini tedavi ederken en çok nelere dikkat edersiniz?

a)Fonksiyon

b)Estetik

c) Çocuğun beslenmesi

d) ̧̇̇lemin kısa sürmesi

7.Konjenital olarak daimi dişi eksik olan çocuk hastanın süt dişini tedavi ederken daha çok hangi restorasyon materyalini ya da materyallerini tercih

edersiniz? (S2)

a)Kompomer

b)Kompozit

c)Cam iyonomer

d)Rezin Modifiye Cam İyonomer

e)Giomer

f)Paslanmaz Çelik Kron

g)Onley

8.Konjenital olarak daimi dişi eksik olan çocuk hastanın süt dişini tedavi ederken kanal ağzını perforasyon durumunda daha çok hangi yöntemi tercih edersiniz?

a)Direkt pulpa kuafajı

b)Vital pulpa tedavisi

c)Kök kanal tedavisi

d) Tedavi etmem

9.Yukarıdaki soruya cevabınız evetse daha çok hangi materyali tercih edersiniz?

a)Therecal

b)Mineral Trioksit Aggregat (MTA)

c) Biodentine (BD)

d)Kalsiyum hidroksit

10.Konjenital olarak daimi dişi eksik olan çocuk hastanın süt dişi çekimini yapar mısınız?

a)Evet

b)Hayır

c)Kararsızım

11.Çekilen süt dişi yerine daha çok hangi protetik rehabilitasyonu tercih edersiniz?

a)Sabit yer tutucu

b) Hareketli yer tutucu

c) Çocuk protezi

d)Kararsızım

12.Konjenital olarak daimi dişi eksik olan süt dişine ileri cerrahi tedavi sizce aşağıdakilerden hangisidir?

a)Süt dişinin möllenmesi

b)Süt dişinin hemiseksiyonu

c) Çekilen yere implant uygulanmas

d)Ototransplantasyon

e)Kararsızım

13.Konjenital olarak daimi dişi eksik olan çocuk hastanın süt dişine daha çok hangi koruyucu uygulamayı tercih edersiniz?

a)Fissür örtücü

b)Flor jel

c)Flor vernik

d)Koruyucu rezin restorasyonu

d)Kararsızım

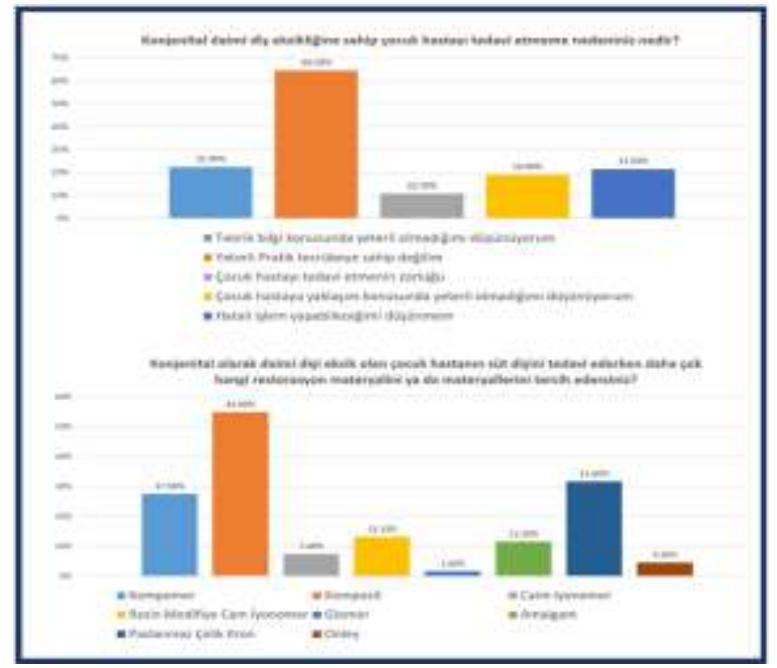

Resim 1. Çalışmada yer alan çoktan seçmeli anket sorularının yanıtlarının dağııımı

Tablo 2. Çalışmada yer alan Türkiye'deki Diş Hekimlerinin $(n=244)$ demografik verileri

\begin{tabular}{|l|l|l|l|}
\hline Demografik veriler & Faktörler & Kişi Sayısı & \% \\
\hline \multirow{2}{*}{ Cinsiyet } & Erkek & 78 & $\% 32$ \\
\cline { 2 - 4 } & Bayan & 166 & $\% 68$ \\
\hline \multirow{2}{*}{ Mesleki Deneyim } & $\leq 10$ Yıl & 224 & $\% 91.8$ \\
\cline { 2 - 4 } & $>10$ Yıl & 20 & $\% 8.2$ \\
\hline \multirow{2}{*}{ Çalıştığı Kurum } & Özel & 127 & $\% 52$ \\
\cline { 2 - 4 } & Devlet & 117 & $\% 48$ \\
\hline
\end{tabular}

Çalışmaya katılanların konjenital daimi diş eksikliğinde tedavi planlaması yaparken; \%78, $1^{\prime} i$ dişin fonksiyon görmesine, $\% 12,9^{\prime}$ u estetiğe, $\% 8,4^{\prime}$ ü çocuğun beslenmesine, \%0,6'sı işlemin kısa sürmesine göre karar vermektedir. Tedavi planlamasında cinsiyet, çalışma yeri ve tecrübe açısından anlamlı bir fark bulunmadı $(p>0,05)$ (Tablo 3). Çalışmaya katılanlardan konjenital daimi diş eksikliğinde süt dişinde restorasyon materyali olarak diş hekimlerinin $\% 54,9^{\prime} \mathrm{u}$ kompoziti, \%31,6'sı paslanmaz çelik kronu, \%27,5'i kompomeri, $\% 13,1^{\prime} i$ rezin modifiye cam iyonomeri, $\% 11,5^{\prime} \mathrm{i}$ amalgamı, \%7,4'ü cam iyonomeri, $\% 4,5^{\prime} \mathrm{i}$ onleyi, \%1,6'sı giomeri tercih etmiştir (Resim 1).

Çalışmaya katılanların konjenital daimi diş eksikliğinde süt dişinde çürük nedeniyle pulpa perforasyonu olduğunda; \%28,3'ü vital pulpa tedavisini, \%29,1'i direkt pulpa kuafajını, \%42,2'si kök-kanal tedavisini seçerken, $\% 0,4$ 'ü süt dişini tedavi etmemektedir. Pulpa perforasyonu olduğunda tedavi seçeneğini belirlerken cinsiyet, çalışma yeri ve tecrübe açısından anlamlı bir fark bulunmadı ( $p>0,05$ ) (Tablo 3 ).

Konjenital daimi diş eksikliğinde süt dişinin tedavi materyali olarak \%13,1'i Biodentini (BD), \%57,4'ü Mineral Trioksit Aggregatı (MTA), \%22, $5^{\prime} \mathrm{i}$

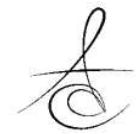


kalsiyum hidroksiti, \%7'si therecali tercih etmiştir. Konjenital daimi diş eksikliğinde süt dişinde çürük nedeniyle pulpa perforasyonu olduğunda materyal tercihinde özel kurumların devlet kurumlarına göre materyal seçiminde cinsiyet ve tecrübe açısından anlamlı bir fark bulunmazken ( $p>0,05)$, çalışma yeri açısından istatistiksel olarak anlamlı fark bulundu $(p=0,010)$ (Tablo 3).

Konjenital daimi diş eksikliğinde süt dişi çekimini diş hekimlerinin \%30,3'ü gerçekleştirirken, $\% 57,8^{\prime i}$ süt dişi çekimi yapmadığını belirtmiştir. Konjenital daimi diş eksikliğinde süt dişi çekiminde cinsiyet, çalışma yeri ve tecrübe açısından anlamlı bir fark bulunmadı $(p>0,05)$ (Tablo 3 ).

Konjenital daimi diş eksikliğinde çekim boşluğunun korunması amacıyla diş hekimlerinin \%67,6'sı sabit yer tutucuyu, \%8,2'si hareketli yer tutucuyu, $\% 11,5^{\prime} i$ çocuk protezini seçerken, $\% 12,7^{\prime}$ si kararsız kalmışır. Çalışmada yer alan diş hekimlerinin çekim boşluğunu korunması konusundaki yaklaşımlarında cinsiyet ve çalışıığı kurum açısından aralarında istatistiksel olarak anlamlı fark bulunurken $(p=0,020$, $p=0,029)$, tecrübe açısından istatistiksel olarak anlamlı bir fark bulunmadı ( $p>0,05)$ (Tablo 3 ).

Konjenital daimi diş eksikliğinde ileri cerrahi tedavi planlamasında diş hekimlerinin $\% 28,7$ 'si implant tedavisini, $\% 15,6$ 'sı ototransplantasyonu, $\% 7,8$ 'si süt dişinin möllenmesini, \%8,6'sı süt dişinin hemiseksiyonunu belirtmişken, \%39,3'ü kararsız kalmıştır. Konjenital daimi diş eksikliğinde ileri cerrahi tedavi planlamasında cinsiyet, çalışma yeri ve tecrübe açısından anlamlı bir fark bulunmadı ( $p>0,05$ ) (Tablo 3 ).

Konjenital daimi diş eksikliğinde süt dişine koruyucu tedavi olarak diş hekimlerinin \%48,4'ü fissür örtücüyü, \%3,7'si flor jeli, \%19,2'si flor verniği, $\% 22,1^{\prime} i$ koruyucu rezin restorasyonu seçerken, $\% 6,1^{\prime} i$ tedavi seçeneğinde kararsız kalmıştır. Konjenital daimi diş eksikliğinde süt dişine koruyucu tedavide cinsiyet, çalışma yeri ve tecrübe açısından anlamlı bir fark bulunmadı $(p>0,05)$ (Tablo 3).

Tablo 3. Çalışmada yer alan anket sorularının istatistiksel verileri (Pearson's $x 2$ tests)

\begin{tabular}{|c|c|c|c|c|c|c|c|c|c|c|c|c|c|}
\hline \multirow{2}{*}{$\begin{array}{l}\text { Anketteki } \\
\text { Sorular }\end{array}$} & \multirow[t]{2}{*}{ Cevaplar } & \multicolumn{3}{|l|}{ Cinsiyet } & \multirow{2}{*}{$\begin{array}{l}\text { p- } \\
\text { değeri }\end{array}$} & \multicolumn{3}{|l|}{ Tecrübe } & \multirow{2}{*}{$\begin{array}{l}\text { p- } \\
\text { değeri }\end{array}$} & \multicolumn{3}{|c|}{ Çalıştığı Kurum } & \multirow{2}{*}{$\begin{array}{l}\mathrm{p}- \\
\text { değeri }\end{array}$} \\
\hline & & Erkek & Bayan & Toplam & & $<10$ & $>10$ & Toplam & & Devlet & Özel & Toplam & \\
\hline \multirow{2}{*}{$\begin{array}{l}\text { Bilgi düzeyi } \\
\text { yeterli mi? }\end{array}$} & Evet & $\% 64,1$ & $\% 47.0$ & $\% 52,5$ & \multirow[t]{2}{*}{ 0,013* } & $\% 52,2$ & $\% 55,0$ & $\% 52,5$ & \multirow[t]{2}{*}{0,812} & $\% 47,0$ & $\% 57,5$ & $\% 52,5$ & \multirow[t]{2}{*}{0,102} \\
\hline & Hayır & $\% 35.9$ & $\% 53.0$ & $\% 47,5$ & & $\% 47,8$ & $\% 45,0$ & $\% 47,5$ & & $\% 53,0$ & $\% 42,5$ & $\% 47,5$ & \\
\hline \multirow{4}{*}{$\begin{array}{l}\text { Nelere dikkat } \\
\text { edersiniz? }\end{array}$} & Fonksiyon & $\% 69,6$ & $\% 82,8$ & $\% 78,1$ & \multirow[t]{4}{*}{0,171} & $\% 78,7$ & $\% 71,4$ & $\% 78,1$ & \multirow[t]{4}{*}{0,782} & $\% 82,4$ & $\% 74,7$ & $\% 78,1$ & \multirow[t]{4}{*}{0,214} \\
\hline & Estetik & $\% 19,6$ & $\% 9,1$ & $\% 12,9$ & & $\% 12,1$ & $\% 21,4$ & $\% 12,9$ & & $\% 7,4$ & $\% 17,2$ & $\% 12,9$ & \\
\hline & Beslenme & $\% 10,7$ & $\% 7,1$ & $\% 8,4$ & & $\% 8,5$ & $\% 7,1$ & $\% 8,4$ & & $\% 10,3$ & $\% 6,9$ & $\% 8,4$ & \\
\hline & $\begin{array}{l}\text { Tedavinin kısa } \\
\text { sürmesi }\end{array}$ & $\% 0,0$ & $\% 1,0$ & $\% 0,6$ & & $\% 0,7$ & $\% 0,0$ & $\% 0,6$ & & $\% 0,0$ & $\% 1,1$ & $\% 0,6$ & \\
\hline \multirow{4}{*}{$\begin{array}{l}\text { Perforasyon } \\
\text { durumunda } \\
\text { tercih edilen } \\
\text { yöntem }\end{array}$} & Kanal tedavisi & $\% 47,4$ & $\% 39,8$ & $\% 42,2$ & \multirow[t]{4}{*}{0,553} & $\% 44,2$ & $\% 20,0$ & $\% 42,2$ & \multirow[t]{4}{*}{0,052} & $\% 34,2$ & $\% 49,6$ & $\% 42,2$ & \multirow[t]{4}{*}{0,079} \\
\hline & Vital pulpa tedavisi & $\% 28,2$ & $\% 28,3$ & $\% 28,3$ & & $\% 28,6$ & $\% 25,0$ & $\% 28,3$ & & $\% 32,5$ & $\% 24,4$ & $\% 28,3$ & \\
\hline & $\begin{array}{l}\text { Direkt pulpa } \\
\text { kuafajı }\end{array}$ & $\% 24,4$ & $\% 31,3$ & $\% 29,1$ & & $\% 26,8$ & $\% 55,0$ & $\% 29,1$ & & $\% 32,5$ & $\% 26,0$ & $\% 29,1$ & \\
\hline & Tedavi etmem & $\% 0,0$ & $\% 0,6$ & $\% 0,4$ & & $\% 0,4$ & $\% 0,0$ & $\% 0,4$ & & $\% 0,9$ & $\% 0,0$ & $\% 0,4$ & \\
\hline \multirow{4}{*}{$\begin{array}{l}\text { Materyal } \\
\text { seçimi }\end{array}$} & Biodentine & $\% 10,3$ & $\% 14,5$ & $\% 13,1$ & \multirow[t]{4}{*}{0,404} & $\% 13,4$ & $\% 10,0$ & $\% 13,1$ & \multirow[t]{4}{*}{0,362} & $\% 18.7$ & $\% 7,9$ & $\% 13,1$ & \multirow[t]{4}{*}{$0,010^{*}$} \\
\hline & MTA & $\% 56,4$ & $\% 57,8$ & $\% 57,4$ & & $\% 57,6$ & $\% 55,0$ & $\% 57,4$ & & $\% 51,3$ & $\% 63,0$ & $\% 57,4$ & \\
\hline & Kalsiyum hidroksit & $\% 28,2$ & $\% 19,9$ & $\% 22,5$ & & $\% 21,4$ & $\% 35,0$ & $\% 22,5$ & & $\% 19,7$ & $\% 25,2$ & $\% 22,5$ & \\
\hline & Therecal & $\% 5,1$ & $\% 7,8$ & $\% 7,0$ & & $\% 7,6$ & $\% 0,0$ & $\% 7,0$ & & $\% 10,3$ & $\% 3,9$ & $\% 7,0$ & \\
\hline \multirow{3}{*}{$\begin{array}{l}\text { Süt molar } \\
\text { dişin çekimini } \\
\text { yapar } \\
\text { mısınız? }\end{array}$} & Evet & $\% 35,9$ & $\% 27,7$ & $\% 30,3$ & \multirow[t]{3}{*}{0,131} & $\% 29,5$ & $\% 40,0$ & $\% 30,3$ & 0,456 & $\% 33,3$ & $\% 27,6$ & $\% 30,3$ & 0,198 \\
\hline & Hayır & $\% 57,7$ & $\% 57,8$ & $\% 57,8$ & & $\% 58,0$ & $\% 55,0$ & $\% 57,8$ & & $\% 52,1$ & $\% 63,0$ & $\% 57,8$ & \\
\hline & Kararsızım & $\% 6,4$ & $\% 14,5$ & $\% 11,9$ & & $\% 12,5$ & $\% 5,0$ & $\% 11,9$ & & $\% 14,5$ & $\% 9,4$ & $\% 11,9$ & \\
\hline Protetik & Sabit yer tutucu & $\% 61,5$ & $\% 70,5$ & $\% 67,6$ & $0,020 *$ & $\% 67,0$ & $\% 75,0$ & $\% 67,6$ & 0,721 & $\% 59,9$ & $\% 74,8$ & $\% 67,6$ & $0,029^{*}$ \\
\hline $\begin{array}{l}\text { rehabilitasyon } \\
\text { tercihi }\end{array}$ & $\begin{array}{l}\text { Hareketli yer } \\
\text { tutucu }\end{array}$ & $\% 15,4$ & $\% 4,8$ & $\% 8,2$ & & $\% 8,5$ & $\% 5,0$ & $\% 8,2$ & & $\% 8,5$ & $\% 7,9$ & $\% 8,2$ & \\
\hline & Çocuk protezi & $\% 14,1$ & $\% 10,2$ & $\% 11,5$ & & $\% 12,1$ & $\% 5,0$ & $\% 11,5$ & & $\% 12,8$ & $\% 10,2$ & $\% 11,5$ & \\
\hline & Kararsızım & $\% 9,0$ & $\% 14,5$ & $\% 12,7$ & & $\% 12,5$ & $\% 15,0$ & $\% 12,7$ & & $\% 18,8$ & $\% 7,1$ & $\% 12,7$ & \\
\hline İleri cerrahi & İmplant & $\% 25,6$ & $\% 30,1$ & $\% 28,7$ & 0,957 & $\% 27,7$ & $\% 40,0$ & $\% 28,7$ & 0,532 & $\% 26,5$ & $\% 30,7$ & $\% 28,7$ & 0,098 \\
\hline tedavi & Ototransplantasyon & $\% 15,4$ & $\% 15,7$ & $\% 15,6$ & & $\% 16,1$ & $\% 10,0$ & $\% 15,6$ & & $\% 20,5$ & $\% 11,0$ & $\% 15,6$ & \\
\hline yöntemi & $\begin{array}{l}\text { Süt dişinin } \\
\text { möllenmesi }\end{array}$ & $\% 7,7$ & $\% 7,8$ & $\% 7,8$ & & $\% 8,5$ & $\% 0,0$ & $\% 7,8$ & & $\% 10,3$ & $\% 5,5$ & $\% 7,8$ & \\
\hline & $\begin{array}{l}\text { Süt dişinin } \\
\text { hemiseksiyonu }\end{array}$ & $\% 9,0$ & $\% 8,4$ & $\% 8,6$ & & $\% 8,5$ & $\% 10,0$ & $\% 8,6$ & & $\% 6,0$ & $\% 11,0$ & $\% 8,6$ & \\
\hline & Kararsızım & $\% 42,3$ & $\% 38,0$ & $\% 39,3$ & & $\% 39,3$ & $\% 40,0$ & $\% 39,3$ & & $\% 36,8$ & $\% 41,7$ & $\% 39,3$ & \\
\hline Koruyucu & Fissür örtücü & $\% 44,9$ & $\% 50,0$ & $\% 48,4$ & 0,177 & $\% 48,7$ & $\% 45,0$ & $\% 48,4$ & 0,202 & $\% 48,7$ & $\% 48,0$ & $\% 48,4$ & 0,869 \\
\hline tedavi & Flor jel & $\% 2,6$ & $\% 4,2$ & $\% 3,7$ & & $\% 3,1$ & $\% 10,0$ & $\% 3,7$ & & $\% 3,4$ & $\% 3,9$ & $\% 3,7$ & \\
\hline & Flor vernik & $\% 18,7$ & $\% 21,1$ & $\% 19,7$ & & $\% 19,7$ & $\% 20,0$ & $\% 19,7$ & & $\% 22,2$ & $\% 17,3$ & $\% 19,7$ & \\
\hline & $\begin{array}{l}\text { Koruyucu rezin } \\
\text { restorasyonu }\end{array}$ & $\% 32,1$ & $\% 17,5$ & $\% 22,1$ & & $\% 23,2$ & $\% 10,0$ & $\% 22,1$ & & $\% 19,7$ & $\% 24,4$ & $\% 22,1$ & \\
\hline & Kararsızım & $\% 3,8$ & $\% 7,2$ & $\% 6,1$ & & $\% 5,4$ & $\% 15$ & $\% 6,1$ & & $\% 6,0$ & $\% 6,3$ & $\% 6,1$ & \\
\hline
\end{tabular}




\section{TARTIŞMA}

Konjenital daimi diş eksikliğinde klinik ve radyografik muayene sonucunda tedavi planlamasına karar verilmelidir. Diş eksikliği nedeniyle eksik olan bölgenin tedavisi konusunda klinisyen doğru zamanda doğru kararı vermelidir. ${ }^{11} \mathrm{Bu}$ amaçla; çocuğun yaşı, büyüme ve gelişmesi, dişin erüpsiyon paterni, durumu ve pozisyonu, arkta yer varlığı ya da yokluğu, hastanın yüz profili ve malokluzyon varlığı göz önünde tutulmaIıdır. ${ }^{12,10}$ Literatürde konjenital daimi diş eksikliğinde tedavi seçenekleri; süt dişinin restorasyonu, süt dişine kök-kanal tedavisi, implant, ototransplantasyon veya süt dişinin çekimi, çekim sonrası sabit veya hareketli çocuk protezleridir. ${ }^{13}$ Diğer taraftan konjenital daimi diş eksikliğinin tedavi gereksinimleri konusunda araştırmacılar tarafından tam bir fikir birliği sağlanamamıştır. Bu amaçla rutin klinikte kullanılan periapikal ve panoramik radyografilerle diş eksikliğinin lokalizasyonu ve sayısı belirlenirken; daha detaylı inceleme için konik ışınlı bilgisayarlı tomografi (KIBT) tavsiye edilmektedir. ${ }^{14}$ Yukarıda saydığımız nedenler doğrultusunda konjenital daimi diş eksikliğine çocuk diş hekimi, ortodontist, ağız diş ve çene cerrahı, protetik diş tedavisi uzmanının yaklaşımı gerekebilir. Bununla birlikte diş hekimlerinin üniversite eğitimleri boyunca çocuk hastanın muayenesini ve tedavisini gerçekleştirdiği bilindiğinden çalışmamızda diş hekimlerinin konjenital daimi diş eksikliği konusunda bilgi düzeylerini ve tedavi yaklaşımlarını ölçmek amaçlanmıştır.

Çalışmamızda konjenital daimi diş eksikliğinde kadınlar erkeklere göre anlamlı olarak yeterli bilgiye sahip olduğunu belirtmiştir. Elde edilen sonuç kadınların çocuklar ile iletişim konusunda daha istekli ve çocuk hastalara karşı duyarlı, hassas ve destekleyici olmalarından kaynaklanmış olabilir. ${ }^{15}$ Bununla birlikte çalışmamızdan farklı olarak Kılınçoğlu ve ark. ${ }^{16}$ ve Öz ve Kırzıoğlu ${ }^{17}$ tarafından yapılan bir çalışmada çocuk hastanın rutin tedavisinde cinsiyet açısından bir farklılık bulunmamıştır.

Çalışmamızda diş hekimlerinin konjenital daimi diş eksikliğinde süt dişinde restorasyon materyali olarak; \%54,9'u kompoziti, \%31,6'sı paslanmaz çelik kronu, \%27,5'i kompomeri, \%13,1'i rezin modifiye cam iyonomeri, \%11,5'i amalgamı, \%7,4'ü cam iyonomeri, \%4,5'i onleyi, \%1,6'sı giomeri tercih etmiştir. Konjenital daimi diş eksikliğinde süt dişinin restorasyon materyali olarak diş hekimlerinin kompoziti, kompomer ve cam iyonomerden daha fazla tercih etmesi kompozitin kompomere göre daha sert, kırılma dayanımının fazla ve yüzey pürüzlüğünün daha az olmasından kaynaklanmış olabilir. ${ }^{18}$ Bununla birlikte Öz ve Kırzıoğlu ${ }^{17}$ tarafından yapılan bir çalışmada diş hekimlerinin süt dişinde rutin tedavide restorasyon materyali olarak kompomeri kompozitten daha fazla tercih ettiği görülmüştür.

Süt dişlerinin yapısını güçlendirmek amacıyla topikal flor uygulaması ve pit ve fissür örtücü koruyucu uygulamalara başvurulmaktadır. ${ }^{19}$ Çalışmamızda fissür örtücü $(\% 48,4)$ uygulamasının flor uygulanmasına (flor jel, \%3,7; flor vernik, \%19,6) göre daha fazla olduğu görülmüştür. Gelişen teknolojiyle birlikte sosyal medyada florun zararlı etkileri daha fazla ön plana çıktığından çalışmamıza katılan diş hekimlerinin koruyucu tedavide flor uygulamasından kaçınmış olabileceği kanısındayız.

Süt molar dişlerin çürük nedeniyle tedavisi sırasında dişte pulpa perforasyonu gerçekleşirse dişin canlılığını korumak amacıyla pulpotomi tedavisi rutin klinikte tercih edilmektedir. ${ }^{20}$ Çalışmamızda ise konjenital daimi diş eksikliğinde süt dişinde çürük nedeniyle pulpa perforasyonu olduğunda diş hekimlerinin kökkanal tedavisini $(\% 42,2)$ vital pulpa tedavisinden $(\% 28,3)$ daha fazla tercih ettiği görülmüştür. Bu sonuç vital pulpa tedavisinin kök-kanal tedavisine göre daha az başarılı bulunduğu yönündeki görüşlerden kaynaklanmış olabilir. ${ }^{21,22}$ Diğer taraftan literatürde konjenital daimi diş eksikliğinde süt molar dişlerin kök-kanal tedavisinde MTA ve gütaperka gibi rezorbe olmayan materyalleri tercih eden araştırmacılar bulunmaktadır. ${ }^{23-25}$ Çalışmamızda diş hekimlerinin konjenital daimi diş eksikliğinde süt dişinde çürük nedeniyle pulpa perforasyonu olduğunda benzer şekilde MTA'yı $(\% 57,4)$ tercih etme oranı oldukça yüksek görülmüştür. Ayrıca devlet ve özel kurumların diş tedavisinde materyal seçiminde istatistiksel olarak anlamlı fark görüldüğü tespit edilmiştir $(p<0,05)$. Özel kurumda yer alan hekimlerin materyal seçiminde imkanlarının daha fazla ve gelişmiş olmasından güncel materyallere ulaşmasının daha kolay olabileceği düşüncesindeyiz.

Son yıllarda konjenital daimi diş eksikliğinde implant uygulaması tercih edilmektedir. ${ }^{26,10}$ Çalışmamızda konjenital daimi diş eksikliğinde diş hekimlerinin $\% 28,7$ 'si implant tedavisinin uygulanabileceğini düşünmektedir. Bununla birlikte literatürde implantın kemikle osseointegrasyon göstermesinin büyüme-gelişme paterni tamamlanmadan uygulandığında infraokluzyona yol açabileceği bildirilmiştir. ${ }^{27} \mathrm{Bu}$ amaçla bireylerin 18 yaşını tamamlamadan implant tedavisi için uygun olmadığı söylenmiştir. ${ }^{28}$

Konjenital daimi diş eksikliğinde süt molar dişlerin alveolar kemiği bukkolingual ve vertikal yönde 
SOĞUKPINAR, TEMUR, HATİPOĞLU

indükleyerek koruması kimi araştırmacıları dişi olabildiğince ağız içinde tutulmasına yönlendirmiştir. ${ }^{29,30}$ Eğer süt dişi 20 yaşına kadar sağıklı ve fonksiyon halindeyse, uzun yıllar daha prognozunun olumlu olacağı düşünülmektedir. ${ }^{30}$ Benzer şekilde çalışmamıza katılan diş hekimleri konjenital daimi diş eksikliğinde süt dişinin çekimini \%57,8'i tercih etmezken, \%30,3'ü çekimi uygun görmüştür. Bununla birlikte konjenital daimi diş eksikliğinde süt 2.molarların çekimine 11 yaşından önce karar verilirse spontan iyileşmenin gerçekleşeceği belirtilmiştir. ${ }^{30}$ Kemik definitesinden kaçınmak amacıyla süt 1.moların çekiminin komşu premolar dişin kökünün yarısı oluşmaya başladığında gerçekleştirilmesini tavsiye eden araştırmacılar da bulunmaktadır. Bu durum 1.premolar dişin eksik olan 2.premolar bölgesine alveolar kemik gelişimini uyararak yerleşmesini sağlayacaktır. ${ }^{31}$

Çekim bölgesine uygun protetik rehabilitasyonu gerçekleştirmek adına çalışmamızda diş hekimlerinin $\% 67,6$ 'sı sabit yer tutucuyu, \%8,2'si hareketli yer tutucuyu, \%11,5'i çocuk protezini tercih ederken, \%12,7'si kararsız kalmıştır. Literatürde konjenital daimi diş eksikliğinde çocuk protezini tercih eden araştırmacılar görülmüştür. ${ }^{14,32}$ Çalışmamızda diş hekimlerinin çekim boşluğuna uygulanacak protetik rehabilitasyonda cinsiyet ve çalıştığı kurum açısından istatistiksel olarak anlamlı fark görülmüştür. Bu fark kadın diş hekimlerinin daha multidisipliner düşünmesinden veya çocuk hastayı tedavi etmede özel kurumda çalışan hekimlerin çocuk hastaya daha fazla zaman ayırmasından ve imkanlarının daha iyi olmasından kaynaklanmış olabilir.

Araştırmanın sınırlııkları ve genellenebilirliği: Çalışmadaki anket sorularının sadece diş hekimi pratisyenlerine yöneltilmesi bu çalışmanın sınırlııklarındandır. İleriki anket çalışmalarında konu hakkında uzman olan çocuk diş hekimlerine ve ortodontistlere uygulanması tavsiye edilmektedir.

\section{SONUÇ}

Konjenital daimi diş eksikliğine tedavi yaklaşımı konusunda tam bir fikir birliğinin sağlanamaması diş hekimlerinin çocuk hastanın tedavi planlaması ve tedavinin uygulanması sürecinde zorlamaktadır. Diş hekimlerinin çocuk hastaya yaklaşımı, tedavi planlamasının uygulanma zorluğu, konu hakkındaki teorik bilgilerinin yetersiz olduğunu düşünmeleri vb. gibi nedenlerle çocuk hastayı uzman diş hekimine yönlendirmeleri kaçınılmaz hale gelebilir. Bu aşamada diş hekimlerinin konjenital daimi diş eksikliğine pratik ve teorik olarak yaklaşımları konusunda eğitimlerin verilmesi ve konu hakkında bilgi edinmeleri gerekmektedir.

NOT: Çalışmada herhangi bir yazar, kurum ya da kuruluş ile çıkar çatışması içerisinde bulunmamaktadır. Makale daha önce hiçbir yerde yayınlanmamış ve yayınlanmak üzere işlem görmemektedir

\section{KAYNAKLAR}

1. Küchler EC, Risso PA, Costa Mde C, Modesto A, Vieira AR. Studies of dental anomalies in a large group of scholl children. Arch Oral Biol 2008; 53: 941-6.

2. Borie E, Fuentes R, Beltran V. Multiple tooth agenesis in nonsyndromic patient: a rare case report. Int J Morphol 2012; 30:634- 6.

3. Sökücü $O$, Ünal $M$, Topcuoğlu $T$, Öztaş $N$. Çocuklarda daimi dentisyonda hipodonti görülme sıklığı. G Ü Diş Hek Fak Derg 2009; 26:33-7.

4. Cunha AS, dos Santos LV, Marañón-Vásquez GA, et al. Genetic variants in tooth agenesis-related genes might be also involved in tooth size variations. Clin Oral Invest 2020. https://doi. org/10.1007/s00784-020-03437-8.

5. De Coster $P$, Marks L, Martens L, Huysseune $A$. Dental agenesis: genetic and clinical perspectives. J Oral Pathol Med 2009; 38:1-17.

6. Parkin N, Elcock C, Smith R, Griffin R, Brook A. The aetiology of hypodontia: the prevalence, severity and location of hypodontia within families. Arch Oral Biol 2009; 54:52-6.

7. Vieira AR, D'Souza RN, Mues G, Deeley K, Hsin $\mathrm{H}-\mathrm{Y}$, Küchler EC, et al. Candidate gene studies in hypodontia suggest role for FGF3. Eur Arch Paediatr Dent 2013; 14:405-10.

8. Creton MA, Cune MS, Verhoeven W. Patterns of missing teeth in a population of oligodontia patients. Int J Prosthodont 2007; 20:409-13. is is:?

9. Ponduri S, Birnie DJ, Sandy JR. Infraocclusion of secondary deciduous molars-an unusual outcome. J Orthod 2009; 36:186-9.

10. Sabri R. Management of congenitally missing second pemolars with orthodontics and singletooth implants. Am J Orthod Dentofacial Orthop 2004; 125:634-42.

11. Kokich VG, Kokich VO. Congenitally missing mandibular second premolars: clinical options Am J Orthod Dentofacial Orthop 2006; 130:437-44.

12. Kokich VG. Early Management of Congenitally Missing Teeth. Semin Orthod 2005; 11:146-51. 
13. Dhanrajani PJ. Hypodontia: etiology, clinical features, and management. Quintessence Int 2002; 33:294-302.

14. Kılınç DG, Sevinç N. Erken yaşta tespit edilen iki oligodonti olgusu. Türkiye Klinikleri J Dent Sci 2012; 18:126-30.

15. Gambetta-Tessini K, Mariño R, Morgan M, Evans $\mathrm{W}$, Anderson V. Stress and health-promoting attributes in Australian, New Zealand, and Chilean dental students. J Dent Educ 2013; 77:801-9.

16. Kılıçoğlu H, Gümrü $A D$, İnal I . İstanbul ilinde serbest çalışan diş hekimlerin in koruyucu ve önleyici tedavi uygulamalarının incelenmesi. Türk Ortodonti Derg 2004; 17:312-22.

17. Öz E, Kırzıoğlu Z. Mezuniyet sonrası diş hekimlerinin pedodontik tedavilere yaklaşımları. Balıkesir Sağlık Bil Derg Cilt 2018; 7:1.

18. Yap AU, Chung SM, Chow WS, Tsai KT, Lim CT. Fracture resistance of compomer and composite restoratives. Oper Dent 2004; 29:29-34.

19. American Academy of Pediatric Dentistry Council on Clinical Affairs. Policy on Use of a Caries-risk Assessment Tool (CAT) for Infants, Children, and Adolescents; Reference Manual 2019:24-8.

20. Moretti A, Oliveira T, Sakai VT, Santos CFd, Machado MAdAM, Abdo RCC. Mineral trioxide aggregate pulpotomy of a primary second molar in a patient with agenesis of the permanent successor. Int Endod J 2007; 40:738-45.

21. Barthel CR, Ro senkranz B, Leuenberg A, Roulet JF. Pulp capping of carious exposures: treatment outcome after 5 and 10 years: a retrospective study, J Endod 2000; 26:525-8.

22. Bjørndal L, Reit C, Bruun G, Markvart $M$, Kjaeldgaard $M$, Näsman $P$, et al., Treatment of deep caries lesions in adults: randomized clinical trials comparing stepwise vs. direct complete excavation, and direct pulp capping vs. partial pulpotomy. Eur J Oral Sci 2010; 118:290-7.

23. Camp J. Pediatric endodontics, endodontic treatment for the primary and young permanent dentition. Pathways of the pulp; 2002:833-9.

24. O'sullivan SM, Hartwell GR. Obturation of a retained primary mandibular second molar using mineral trioxide aggregate: a case report. J Endod 2001; 27:703-5.

25. Tunc ES, Bayrak S. Usage of white mineral trioxide aggregate in a non-vital primary molar with no permanent successor. Aust Dent J 2010; 55:92-5.
26. Sabri R. Cleft lip and palate management with maxillary expansion and space opening for a single-tooth implant. Am J Orthod Dentofacial Orthop 2000; 117:148-55.

27. Thilander B, Odman J, Lekholm U. Orthodontic aspects of the use of oral implants in adolescents: a 10-year follow-up study. Eur J Orthod 2001; 23:715-31

28. Yap AK, Klineberg I. Dental implants in patients with ectodermal dysplasia and tooth agenesis: a critical review of the literature. Int J Prosthodont 2009; 22:268-76.

29. Kokich VG: Managing orthodontic-restorative treatment for the adolescent patient, in McNamara JA, Brudon WL (eds): Orthodontics and Dentofacial Orthopedics. Ann Arbor, MI, Needham Press; 2001,423-52.

30. Bjerklin K, Bennett J. The long-term survival of lower second primary molars in subjects with agenesis of the premolars. Eur J Orthod 2000; 22:245-55.

31. Higuchi KW. Ortho-integration: the alliance between orthodontics and osseointegration. In: Higuchi KW, editor. Orthodontic applications of osseointegrated implants. Chicago: Quintessence Co; 2000,1-19.

32. Peker MS, Türker ŞB, Çapan B, Akyüz S, Biren S. İzole çoklu diş eksikliği olgusuna multidisipliner yaklaşım bir yıllık takip. Atatürk Üniv Diş Hek Fak Derg 2015; 25:369-75.

\author{
Sorumlu Yazarın Yazışma Adresi \\ Aslı SOĞUKPINAR \\ Kahramanmaraş Sütçü İmam Üniversitesi Diş \\ Hekimliği Fakültesi, Sağlık Uygulama ve \\ Araştırma Hastanesi 1. Kat E Koridoru Avşar Mah. \\ Batı Çevre Yolu Bulv. No: 251/A 46040 \\ Onikişubat/Kahramanmaraş \\ İş telefonu: (0344) 3003894 \\ Telefonu: 05076014870 \\ e-mail: aslisdt@gmail.com
}

